\title{
The Main Problems Of The Students At Primary LeVEl INRURAL AREA OfTEHSIL: FEROZWALA, District: SHEIKHUPURA- PAKISTAN
}

\author{
Muhammad Faisal Hashami \\ School Health and Nutrition Supervisor Health Department, District Sheikhupura \\ Government Of The Punjab
}

\begin{abstract}
This paper investigates the main problems of the students at primary education level in rural area of Tehsil: Ferozwala, District: Sheikhupura. "Education for all" is a global slogan of "TheGovernment of Pakistan' andis committed to achieve it. However in Pakistan one third population of the total is living in the rural areas and among those very rare ration have knowledge about its importance. The present study was conducted in rural area of Tehsile: Ferozwala, District: Sheikhupura-Pakistan. In this Tehsile, there are 21 Union Councils, in which 06 urban and 15 rural. The total strength of the Primary Schools in the area of rural is $\mathbf{4 6 3}$ for the year of 2015 and the total strength of the students are 18957. Only 100 students are interviewed, among those 50 are male \&50 are female.The results founded that there are a lot of reasons, who create hurdles to get education. In this regard mostly students are deprived from getting the basic education.Finally, suggestions are given at the end of paper.
\end{abstract}

\section{KEY WORDS}

Social, Cultural \& Economical Problems

\section{INTRODUCTION}

Education plays a key role in the development of a country.It is a process of learning which aimed to raises people's creativity morally, social \& culturally. Siddiqui(2013) said that "Education, being the third eye, not only differentiates living being from dead, but also brings rapid growth and development". Education is very important and basic right of every human being.Jawad and Waheed (2014) reflect the same point of view that"Education is the basic right of every human being, irrespective of age, sex and religion, etc." Only an educated person has the ability to take right decision at right time. No one country can achieve its targets/goals without the educated force. Education is essential component for the development and growth of any country. Without education, no any nation has idea about the utilization of the sources in better way.Another placeSiddiqui(2013)also said that "No nation can progress in globalization without education".Education is considered main pillars of a society and the students are its main stockholder. Only those nation got make progress, who gave proper attention to their education. Ahmad et al. (2013) illustrate that "It is an established fact that in the world only those nations have made progress and development which have a sound education system".

Pakistan is under developed country and has bulk of population. According to the Khan (2010) said "Pakistan is one of the most populated countries in the world". More than its half population is living in rural areas among the total. Among those a huge majority is uneducated and unaware about the importance of the education. So, they never spend their children to schools DOI: $10.5121 /$ ije.2016.4101 
for getting education. In Pakistan, the definition of a literate person is this, "a person whocan read a newspaper and write a simple letter, in any language"("Needs Assessment Report on "Literacy Initiative for Empowerment (Pakistan)," 2008). The definition of a literate person is not according to the international standards in Pakistan.

At the birth of Pakistan (14th of August 1947) the condition of education system was very miserable in Pakistan.Suleman et al. (2012) said that "It is a reality that Pakistan is one of those very few countries where education system has constantly eroded since independence". Now the present situation is so worst, due to poor education system. According to Ahmad (2013) that "Pakistan whole educational system is so much deteriorated, ruined and miserable". Its main reason is behind this that the whole education system is inherited from British colonial era.Pakistan is a signatory of education for all. Almost all its education policies did not give fruitful result from the first ones to till now. Our education system is far below from universal primary education access.Pirzado (2006) elaborated that "Pakistan is also a signatory of Education for All (EFA) document, but the target of achieving Education for All is still evasive".

In Pakistan the total education system is deprive from the basic needs like lack of Basic Infrastructure, Lack of Teacher Commitment and Lack of Library, Scientific \& Computer Laboratories etc. which are necessary for getting education. Its main reason is behind insufficient funds for education systems in Pakistan as compare to developed countries. The allocation of funds for education sector by the Government of Pakistan are very low; only $2 \%$ of the total GDP. ("Education: the major problem in Pakistan," 2014). Due to the insufficient funds, the rural schools condition is very bad and there is no much facility for the students as compare to urban schools. Ahmad et al. (2013) strengthen the same point of view that "The conditions of primary schools in the rural areas are more deplorable than in the urban areas". So a huge ratio of the students has no interest to go to school due to the rural schools' bad condition. They fed up and left school in early age

On one side education is considered a powerful tool to bring change in any society but on the other hand its deprivation from basic needs show its failure in the society. In this critical situation, no one nation can achieve its defined goal and literacy rate would not increase.

\section{STATEMENT OF THE PROBLEM}

Khalid (1998) pointed out that "Learning process is considered as training in the field of morals for individuals through which their potentialities are developed, the qualities and traits of the creator are infused in them". In Pakistan our education system is deliberately neglected. So for our literacy rate is very low all over the world after the 68 years of its freedom. However the purpose of this study is to analyze the main causes of the students which they faced during study in schools at rural area of Tehsil: Ferozwala, District: Sheikhupura- Pakistan Problems faced by Students

According to the present investigation, there are so many problems in students' education. The following problems are elaborated under below:

\section{Poverty}

Pakistan is one among underdeveloped countries where majority of people lives below the poverty line. They cannot bear the expenses of their children's educational requirements (like, pen, pencil, uniform, shoes, etc. A large number of children work as a labor in workshops, factories agri-fields, etc., to earn livelihood and sport their poor families. In such a state of affairs 
a bad impact is inevitable on the students mental capability, therefore children from poor families can't continue their education by losing whim \& interest in education. Secondly, Mostly Parents prefer to send their children to madrassas where education is totally free. ("Education: the major problem in Pakistan," 2014)

\section{Lack of Basic Infrastructure}

The educational system of Pakistan is based on unequal lines. Medium of education is different in both, public and private sector. This creates a sort of disparity among people. ("Education: the major problem in Pakistan," 2014).It is a commonly observed that in public schools have no basic facilities but on the other hand private schools' condition is totally different. In the study area that mostly students have no proper class room paraphernalia are available. It is noted that at least one third schools contain only one or two class rooms and without any sitting arrangements. All the students are forced to make their own arrangement like tat, brick, used sack, etc. It is critical situation and causes to shatter the morale of the students. That very situation also indicates that students are deprived of their basic necessaries of education.

\section{Lack of Library, Scientific \& Computer Laboratories}

In study are not a single school has any library facility, audio-video support and Computer Laboratories. While these facilities are considered very necessary instruments of the education, which play a great role in the student's grooming. Actually teaching aids help and build student's concepts. Due to weak conceptual base students loose their interest in studies.

\section{Transfer of Teacher}

Transfer of teacher from one place of job to other place of employment is another huge problem. The transfers the school teachers not only disturb but also create a bad impact on the education process of concerned students. If takes time to und--erstand the teacher's method of instruction while sudden transfer of teachers disturb badly the education of the children. It is seen that most of students cannot easily shift to any new teaching method of new appointed teacher very easily. So a lot of time is required to understand new teaching method. This practices results in wastage of time and effort and hamper badly the education processes.

\section{Lack of Teacher Commitment}

Basically teachers are thought to be instruments of change in the society. However, it is observed a majority of teachers did not pay attention toward their commitment. New ways of teaching are not adopted rather they attend the school just for enjoying themselves and passing the time. As a result neglected students may fell into wrong. Most of the school students run away from the school to indulge in wasteful activities. Ultimately students lose their interest in education and left education institution in an early age.

\section{Teachers' out of date Knowledge base}

The modern age is full of opportunities. To avail these opportunities only will is a requisite factor. Opportunities to update oneself are also many. Teachers are direly needful of updating their knowledge regarding the modern theories and practices of education in case when they have no concept of educational modern theories and are not aware of new concepts of relevant subject logically he will use the old methods of teaching and out dated theories. In this way students are deprived of new knowledge. Resultantly they will not be able to complete and lose their whim for 
further learning.In Pakistan, People who do not get job in any other sector, they try their luck in educational system. They are not professionally trained teachers so they are unable to train a nation. ("Education: the major problem in Pakistan," 2014)

\section{Lack of Appreciation of Students}

Lack of appreciation is another huge problem for the students to take then on the road of success. According to Siddiqi (2012) that "Lack of appreciation, acceptability and growth chance has caused the disaster of the brilliant brains of nation."Generally students are not appreciated on their best performance in spite they are appreciated and recognized on the basis of their financial and social status. This factor discourages the students, who lack strong social background. In the long run they will never work hard because they know that they will never be appreciated on their best performance.Siddiqi (2012) also reflects the same point of view that "In Pakistan the punishment is considered as compulsory for teaching purposes." this factor who put back the student from their education.

\section{Lack of Co-Curricular Infrastructure}

Co-curricular activities play a big role in the physical and mental development of a child. However in the study area no one school has even proper play ground for the students physical grooming. Whenever students did not participate in co-curricular activities then how he can be a healthy physically fit and mentally sound person. According to the famous quotation, which read: "A sound body has a sound mind"

\section{Proper Medical Facility}

In Pakistan the medical condition -is very poor especially for the common people. Our government spend very short amount on the health, which is not enough. The government should give proper attention on this sector, especially. According to Akram and khan (2007) "Government spends its expenditures in health sector just $0.7 \%$ per year but it's not enough for massive populated areas in developed country like Pakistan". In the study area, no medical facility is available at school level. Eye and skin problems have been identified in most of the students of the area. The distances between schools and basic health facilities are long to be approached easily die to lack of transport means. Therefore students could not access the Basic Health Unit for getting medical care and aid. Mostly ailing students recover from their disease and ailments after protracted periods. In the study area, medical consultancy available is the level of a dispenser instead of a specialized physician.

\section{Cram}

Cram is identified as big hurdle for the students to construct a strong conceptual base. Those students, who can understand the topics of the text books they can successfully solve the paper. While students who are unable to understand the concepts they try to learn by heart (ratta) without perceiving anything. So ratta is the main source for damaging the IQ of common students who try to pass the examination through rattainspite of passing his examination in his practical life. He cannot make any difference. He earns only simple and substandard life as they attempted their examinations in the same way. Gravity of the problem could not be sensed through the fact that

\section{OBJECTIVES OF THE STUDY}

The study was conducted with the following objectives; 
- To study the social, economic and cultural problems faced by the students during study.

- To evaluate the government teachers role regarding the development of children.

\section{METHODOLOGY}

According to the nature, it is descriptive study. The population of the study were all Government PrimarySchools of Tehsil: Ferozwala, District: Sheikhupura-Pakistan. After the selection of the study area, the author design a questioner, which was consists on twelve questions. For the checking of the questionnaire, the author pretest it on the five students. The author felt that there were some flaps in the questionnaireso hemade it some necessary amendments, and also included the open hand questions among those. After the competition of the questionnaire, ten schools were selected with simple random sampling technique.Among those schools one hundred students were interviewed (fifty boys and fifty girls). The present study was concentrated to inquire about the main reasons of the students; i.e. socially, economic and culture problemsthat' was the cause, they left school in their early age.

\section{HYPOTHESES}

The following hypotheses were formulated for the study;

O Only those students were interviewed, who are living in the same union council where Government school is consists.

$\circ$ Allstudents were interviewed when they will out from of the school' treaty.

\section{DATA}

Table-1. Sex wise distribution of the Students

\begin{tabular}{|c|c|c|}
\hline Sex & F & $\%$ \\
\hline Boys & 50 & 50 \\
\hline Girls & 50 & 50 \\
\hline Total & 100 & 100 \\
\hline
\end{tabular}

Table-2. Students' family background

\begin{tabular}{|c|c|c|}
\hline Family Background & F & $\%$ \\
\hline Urban & 17 & 17 \\
\hline Rural & 83 & 83 \\
\hline Total & 100 & 100 \\
\hline
\end{tabular}

Table-3 Economic condition of the Students family

\begin{tabular}{|c|c|c|}
\hline Economically condition & F & $\%$ \\
\hline Belong Very Poor family & 38 & 38 \\
\hline Belong Poor Family & 27 & 27 \\
\hline Belong Normal Family & 24 & 24 \\
\hline Belong Rich Family & 11 & 11 \\
\hline Belong Very Rich Family & -- & -- \\
\hline Total & 100 & 100 \\
\hline
\end{tabular}


International Journal of Education (IJE), Vol. 4, No. 1, March 2016

Table- 4 Source of their Father's income

\begin{tabular}{|c|c|c|}
\hline Father's income sources & F & \% \\
\hline Working in agriculture fields & 37 & 17 \\
\hline Working in Private sector (Wok shop etc) & 17 & 13 \\
\hline Working in Government sector (as Govt. Employee) & 13 & 21 \\
\hline Work anywhere else & 21 & 12 \\
\hline Never work in any field & 12 & 100 \\
\hline Total & 100 & \\
\hline
\end{tabular}

Table- 5 If never work in any field than what was the reason

\begin{tabular}{|c|c|c|}
\hline Reasons & F & $\%$ \\
\hline Have a lot of resources & -- & -- \\
\hline Have any disability & 08 & 75 \\
\hline Have no interest to work any where & 04 & 25 \\
\hline Total & 12 & 100 \\
\hline
\end{tabular}

Table- 6 Your School has its building

\begin{tabular}{|c|c|c|}
\hline School building & F & $\%$ \\
\hline Yes & 83 & 83 \\
\hline No & 17 & 17 \\
\hline Total & 100 & 100 \\
\hline
\end{tabular}

Table- 7 If yes than, School Building was contain on

\begin{tabular}{|c|c|c|}
\hline Rooms & F & --- \\
\hline 1 to 2 Rooms & -- & 07 \\
\hline 2 to 3 Rooms & 06 & 41 \\
\hline 3 to 4 Rooms & 34 & 52 \\
\hline More than 4 Rooms & 43 & --- \\
\hline Have no a single Room & --- & 100 \\
\hline Total & 83 & \\
\hline
\end{tabular}

Table- 8 Sitting arrangement for the students (in the school)

\begin{tabular}{|c|c|c|}
\hline Sitting Arrangements & F & $\%$ \\
\hline Benches & 15 & 18 \\
\hline Brick & 08 & 10 \\
\hline Tat / Sack & 60 & 72 \\
\hline Total & 83 & 100 \\
\hline
\end{tabular}


International Journal of Education (IJE), Vol. 4, No. 1, March 2016

Table- 9 Availability of the Education facilities (Library, Scientific \& Computer Laboratories)

\begin{tabular}{|c|c|c|}
\hline Availability of educational facilities & F & $\%$ \\
\hline Yes & -- & -- \\
\hline No & 100 & 100 \\
\hline Total & 100 & 100 \\
\hline
\end{tabular}

Table- 10 If No, than which method they used to understand the lesson

\begin{tabular}{|c|c|c|}
\hline Understand the lesson & F & $\%$ \\
\hline Through Ratta system & 82 & 82 \\
\hline Through get guidance of the seniors & 18 & 18 \\
\hline Total & 100 & 100 \\
\hline
\end{tabular}

Table- 11 Teachers are commanded with their profession

\begin{tabular}{|c|c|c|}
\hline Teachers' Commandment & F & $\%$ \\
\hline Yes & 11 & 11 \\
\hline No & 89 & 89 \\
\hline Total & 100 & 100 \\
\hline
\end{tabular}

Table- 12 If yes than have they knowledge about the modern syllabus

\begin{tabular}{|c|c|c|}
\hline Knowledge about the modern syllabus & F & $\%$ \\
\hline Yes & 03 & 27 \\
\hline No & 08 & 73 \\
\hline Total & 11 & 100 \\
\hline
\end{tabular}

Table- 13 If no than the main reasons

\begin{tabular}{|c|c|c|}
\hline Reasons & F & $\%$ \\
\hline Most senior (near to the retirement) & 09 & 10 \\
\hline Teachers have no interest to learn it & 80 & 90 \\
\hline Have no idea & --- & --- \\
\hline Total & 89 & 100 \\
\hline
\end{tabular}

Table- 14 Your school teachers transferred from one to other schools (within one year)

\begin{tabular}{|c|c|c|}
\hline Transfer & F & $\%$ \\
\hline Yes & 32 & 32 \\
\hline No & 68 & 68 \\
\hline Total & 100 & 100 \\
\hline
\end{tabular}


International Journal of Education (IJE), Vol. 4, No. 1, March 2016

Table- 15 If yes, than how many time

\begin{tabular}{|c|c|c|}
\hline & $F$ & $\%$ \\
\hline One time & 16 & 50 \\
\hline Twice time & 09 & 28 \\
\hline Three time & 05 & 16 \\
\hline Four time & 02 & 06 \\
\hline Total & 32 & 100 \\
\hline
\end{tabular}

Table- 16 Appreciate on the best performance

\begin{tabular}{|c|c|c|}
\hline Appreciate on the performance & F & $\%$ \\
\hline Yes & 05 & 05 \\
\hline No & 95 & 95 \\
\hline Total & 100 & 100 \\
\hline
\end{tabular}

Table- 17 If yes than in which kind

\begin{tabular}{|c|c|c|}
\hline & F & $\%$ \\
\hline In orally shape & -- & 00 \\
\hline By money & 04 & 80 \\
\hline By gift (such as pen, book etc.) & 01 & 20 \\
\hline Total & 05 & 100 \\
\hline
\end{tabular}

Table- 18 Availability of medicine facility (in school treaty)

\begin{tabular}{|c|c|c|}
\hline Availability of medicine facility & F & $\%$ \\
\hline Yes & 02 & 02 \\
\hline No & 98 & 98 \\
\hline Total & 100 & 100 \\
\hline
\end{tabular}

Table- 19 If yes than source of medical treatment

\begin{tabular}{|c|c|c|}
\hline & F & $\%$ \\
\hline Dispensary (Public / Private) & 02 & 100 \\
\hline Quack & --- & --- \\
\hline Total & 02 & 100 \\
\hline
\end{tabular}

\section{Analysis Of StUdy Finding}

1. The respondents were equally distributed according to the sex. Exactly (50\%) are boys and (50\%) girls. (Table No.1)

2. The respondents were distributed according to the family background. A little ration (17\%) belong to urban areas and remaining (83\%) Belong to Rural area. (Table No.2) 
3. The respondents were distributed according to the economic condition of the students' family. A Little ratio $(11 \%)$ belong to very rich family and $(38 \%)$ belong to very poor family, and (27\%) said they belong to poor family and $24 \%$ belong normal family. (Table 3)

4. The respondents were distributed regarding the source of their father income, which they earn from different professions. From the total respondents, $(37 \%)$ said that they earn their income from agriculture sector, $(21 \%)$ earn their income from different sources, $(17 \%)$ has earned from the private sector, $(13 \%)$ earned their income from Government sector and very small ratio $(12 \%)$ never work in any field. From the total respondents, who are not working in anywhere, majority (75\%) have physical disability and exactly one fourth (25\%) have no interest to work in any field. (Table 4 and 5)

5. The respondents were distributed according to the school building. A huge ratio (83\%) said that their school has its own building and vary small ratio (17\%) said they have no. From the total respondents, whom school have its own school building, nearly half (52\%) respondents said that they have more than four rooms, $(41 \%)$ said their school's building is consist on three to four rooms, and very small $(07 \%)$ ratio said their school's building is consist on two to three rooms. (Table 6 and 7 )

6. According to the distribution of respondents regarding sitting arrangements in school, a huge ratio $(72 \%)$ use tat/sack for sitting, (18\%) use Benches and very rare ratio (10\%) use Bricks. (Table8)

7. According to the respondents, no-one had availed the education facilities (Library, Scientific \& Computer Laboratories) in these schools from the government side. From the total respondents, who have no single opportunity of education facilities from the government side. A little ratio (18\%) said they understand their lesson through the guidance of the seniors and majority (82\%) said they understand their lesson through rata system. (Table 9\& 10)

8. The respondents were distributed regarding their teachers' command on teaching profession. A little ratio (11\%) said their teachers have command on teaching profession and a huge ratio (89\%) said their teachers have no. From the total respondents, who said their teachers have command on teaching profession. (27\%) said their teachers have knowledge about the modern syllabus and (73\%) said their teachers have no knowledge about modern syllabus. From the respondents, who said their teachers have no command on teaching profession. A little ratio (10\%) said their teachers are most senior in the school so they have no command on teaching profession and (90\%) said that their teachers have no interest to get knowledge about the new syllabus. (Table 11, 12, \& 13)

9. According to the distribution of the respondents regarding the transfer of their school teachers within one year. Nearly one third (32\%) respondents said that their teachers have transfer to another school within one year and $(68 \%)$ said their teachers have no. from the total respondents of the total, whom teachers have transfer from one to another school, exactly $(50 \%)$ respondents said that their teachers have transfer one time. (28\%) have transfer twice time within one year, and (16\%) said their teachers have transfer three times, while $(06 \%)$ said that teachers have transfer four times within one year. (Table $14 \& 15$ ) 
10. The respondents were distributed according to the appreciation on their best performance in the study field. Whelming majority of the respondents (95\%) said they have no and very small ratio of the respondents $(05 \%)$ has appreciated on their best performance. Among the total respondents, who have appreciated in the study field, $(80 \%)$ said they have appreciate by money and (20\%) said they were appreciated by gift such as pen, book etc. (Table $16 \&$ 17)

11. According to the respondents regarding the availability of the medicine (in school treaty). Majority (98\%) have no avail the medicinal facility and a little ratio $(02 \%)$ has medical facility (in school treaty). From the total respondents, who had availed medical facility in the school treaty, All the respondents (hundred percent) expressed that that facility from Dispensary (Public / Private). (Table 18 \& 19)

\section{RESULTS AND DISCUSSION}

In the Constitution of Islamic Republic of Pakistan that "The state of Pakistan shall remove illiteracy and provide free and compulsory secondary education within minimum possible period."("Education expert call for legislation on Universal Primary Education (UPE)", (2010 September 01). Butit has been observed that in countryside mostly students are deprived from the basic facilities of the education, which are necessary for getting education like Proper Medical Facility and Scientific Library \& Computer Laboratories etc.If someone (student) who is willing to get education, he is deprive form the education because of the no availability of basic facilities of education. Our government did not pay full attention to this sector, which is concern with the development of the nation. Here is no proper check and balance system in this department, this thing take to him in bad situation. At least in this situation everyone loses one's interest in education.

\section{CONCLUSION}

According to Nelson Mandela "Education is the most powerful weapon which you can use to change the world."If you want to destroy the future of any nation, no need to wage war with them; defunct their education, they will remain no more live on the map of the world.Pakistan educational system is getting very pathetic, if higher authority will not take noticed and controlled, then the future of whole nation will be very miserable.

In the study area, all the schools are deprived from the basic facilities of the education like library, equipment of the scientific laborite, Computer lab, proper class rooms and its furniture. Even students have no playground for their refreshment in leisure time. In this discouraging situation, no one student can give proper attention towards the one's education and can't show off one's capabilities. Ultimately in this result the student lose their interest form the study. And at a time they left the education.

\section{RECOMMENDATION}

Students are the future of any nation. In study area, mostly students are deprived form their rights, which can play a great role in the development of their education. The Government should take solid steps regarding this;

1. Government should provide the basic facilities of the education to the students like as proper class rooms and furniture, Library, Scientific Laborite with latest equipment and proper Computer Lab. 
2. There should be the area of the playground in the school premises for the refreshment of the students.

3. Government should provide the proper medical facility to the students so that they can grow up in better up.

4. Government should provide scholarship to the intelligent students for their encouragement in education.

5. Teachers should appreciate to the students on their performance in the class.

6. Texts books must be up-dated with current topics (affairs) and rapidly changing of the scenario of the world, must be given in the textual books.

\section{REFERENCE}

[1] In Private Sector Relating to Elementary Education in the Province of Sindh." Unpublished thesis of Doctor of Philosophy in Education. University of Sindh, Jamshoro. Pakistan.

[2] Jawad, A., \&Waheed, S. (2014, December). Gender Based Dropout at Primary Level in Rural Areas of District Rawalpindi. Humanities and Social Sciences, Vol. 21, No.02, 25-40.

[3] Ahmad, I., Rauf, M., \& Rashid, A. et al., (2013, March). Analysis of the problems of primary education system in Pakistan: Critical review of Literature. Academic Research International, ISSNL: 2223-9553, ISSN: 2223-9944, Vol Siddiqui, F.K. (2013). "A Critical Study of the Problems of Educational Management. 04 No. 02, 324-331.

[4] Khan, B. S. (2010). "Problems in Universalization of Primary Education in Pakistan. Pakistan journal of commerce and social sciences, Vol. 04, No.02, 147-155.

[5] Needs Assessment Report on "Literacy Initiative for Empowerment (Pakistan). (2008, Janurary). Ministry of Education, Government of Pakistan, Islamabad, p. 16.

[6] Suleman, Q. Hussain, D.I, \& Butt, D. M.N. et al., (2012, November 03). Identification of the Problems faced by Secondary School Teachers in Kohat Division, Pakistan. International Journal of Learning \& Development, ISSN: 2164-4063, Vol.02, No. 05, 324-340.

[7] Pirzado, P. (2006, April). Exclusion of girls from education in rural Pakistan. Institute for Educational Development, Karachi. EENET Asia Newsletter (2), 24-25.

[8] Education: the major problem in Pakistan. (2014, August 15) Retrieved September 15, 2015 from http://www.pakistantoday.com.pk/2014/08/15/comment/education-the-major-problem-in-pakistan/

[9] Khalid, T. (1998). Education an Introduction to Educational Philosophy and History.National Book Foundation, Islamabad, Pakistan. Page No.04.

[10] Siddiqi, A.R. (2012, May 3). Some of the problems faced by students in Pakistan, Retrieved September 15, 2015. from http://saypeople.com/2012/05/03/some-of-the-problems-faced-by-studentsin-pakistan/

[11] Akram, M. \& Khan, F.J (2005) "Health Care Services and Government Spending in Pakistan", PIDE Working Paper 2007:32.

[12] Education expert call for legislation on Universal Primary Education (UPE), (2010, September 01), Retrieved October 11 , 2015. Fromhttp://www.thefreelibrary.com/Education+expert+call+for+legislation+on+UPE.-a0236297815

[13] Sources for speakers on Global Issues: Education for All (EFA). Retrieved October 11, 2015 from http://www.un.org/en/globalissues/briefingpapers/efa/quotes.shtml 